\title{
TITLE
}

\section{Urban Peripheries - Blind Spaces of Cultural Policies?}

\section{AUTHOR}

\section{Walter Rohn}

Institute for Urban and Regional Studies

Austrian Academy of Sciences

Vienna and

Institute for Political Science

University of Vienna

Vienna

\section{BIOGRAPHY}

Born 1957 in Korneuburg, Austria.

Studies of political and communication sciences at the University of Vienna

Ph. D. degree in 1987

Scientist at the Institute for Urban and Regional Studies of the Austrian Academy of Sciences (since 1988)

Lecturer in political science at the University of Vienna (since 2002)

Member of the works council of the Austrian Academy of Sciences (since 2003)

Current research interests:

Cultural facilities and development of urban peripheries

Art avant-garde in Vienna after 1945

International communication policy

\section{ABSTRACT}

The paper deals with new cultural facilities in the (semi-) peripheries of Vienna, Paris and Rome, their impact on urban development, and their association with cultural policies. France and Italy as well as Paris and Rome established early strategies for the cultural advancement of the capital cities' peripheries. In Vienna the bulk of the municipality's cultural funding still is focused on activities in the central parts of the city. It was only recently that the outskirts of Vienna experienced the establishment of several new cultural facilities, most of them of small or medium scope. On the basis of a comparison between Vienna, Paris and Rome, the paper discusses the functions of cultural projects as tools for the physical, spatial, economic, and social development of cities. In the conclusion, recommendations for a cultural policy in support of urban peripheries are presented.

\section{KEYWORDS}

Cultural policy; policy recommendations; urban peripheries; spatial, economic and social development of urban fringe areas; research project 


\section{ARTICLE}

\section{Introduction}

In the 1990s, peripheral and semi-peripheral areas of European cities experienced a tremendous cultural boom. For example in Paris (Opéra Bastille and Oberkampf quarters, Ménilmontand), Rome (Testaccio/Ostiense area), London (Tate Modern on Southbank), and in Zurich (Zürich West) a broad range of new cultural facilities was set up. Of course, these are examples of different types and scopes. In the late 1990s this trend also reached Vienna. Since then many new cultural facilities such as theatres, cinemas, music clubs, art galleries, exhibition spaces, art fairs, and festivals were established on the outskirts of the Austrian capital.

The research project New Culture on the Outskirts of Cities - funded by the Austrian Academy of Sciences and the municipality of Vienna - deals with the issues of culture and urban development. In the context of this project, new cultural initiatives in the urban peripheries/semi-peripheries of Vienna, Paris and Rome, and their impact on local urban development, are studied.

This paper's forthcoming chapters are organised as follows: Chapter 2 deals with the spatial distribution of Vienna's cultural funding. Chapter 3 depicts the recent boom of cultural facilities on the outskirts of the Austrian capital. A comprehensive overview of the theoretical assumptions, the basic research questions and the research design of the mentioned study is given in Chapter 4. Chapter 5 offers a comparison of cultural trends in the urban (semi-) peripheries of Vienna, Paris and Rome as well as a typology of cultural facilities' effects on local urban development. In the conclusion, recommendations for a cultural policy in support of urban peripheries are presented.

\section{Vienna's cultural policy: Spatial aspects of funding}

Funding of cultural institutions and activities in Vienna is based on a dual system. The largest cultural institutions, such as theatres, opera houses and museums, which are basically located in the inner parts of Vienna (districts 1 to 9), are funded by the state. The municipality of Vienna finances or co-finances cultural facilities, which for the most part may be classified as second level institutions. Besides, many cultural institutions attract funding from both the state and the city of Vienna.

The Art and Culture Report of the City of Vienna 2004 (Geschaeftsgruppe Kultur und Wissenschaft 2004: $119 \mathrm{ff}$.) lists all the cultural institutions, facilities and programmes that the municipality of Vienna finances or cofinances. Inter alias the city sponsors museums and exhibition spaces like Museumsquartier, Jüdisches Museum, Künstlerhaus, and Albertina. In the field of music the Wiener Symphoniker and Vienna Art Orchester, Wiener Konzerthausgesellschaft, Wiener Kammeroper, Vereinigte Bühnen Wien, Arnold Schönberg-Center, MICA, and jazz club Porgy \& Bess receive funding from the municipality. Theatres financed or co-financed by the city of Vienna are Theater in der Josefstadt, Volkstheater, Schauspielhaus, Ensemble Theater, Gruppe 80, Odeon, Theater der Jugend and Tanzquartier Wien. Additionally, the municipality allocates money to a broad range of socalled free theatre associations. With respect to the seventh art the municipality sponsors the production of films in Vienna (Filmfonds Wien), the annual film festival Viennale, Filmarchiv Austria and Metro cinema, Stadtkino, and the Austrian film museum. Other important festivals, which are benefited by funding from the city, are the Vienna art festival (Wiener Festwochen), Klangforum Wien, Klangbogen, Wien-Modern, Jazz Fest Wien, ImPuls Tanz and Literatur im März. Furthermore, Werkstätten- und Kulturhaus, the preservation of historical buildings in the city centre and the activities of the Vienna tourist agency are financed by the cultural budget of the city of Vienna. 
The mentioned cultural facilities and activities almost entirely relate to the city centre or the inner districts of Vienna. A closer look at the information provided by the Art and Culture Report 2004 further stresses the concentration of Vienna's cultural budget in terms of resources and space. More than half (52\%) of the total cultural budget of 171 mill. (2004) is devoted to the following institutions and activities: Vienna tourist agency, Theater an der Wien (including Klangbogen-festival), the orchestra Wiener Symphoniker, the Vienna art festival, preservation of buildings, support of film production on location, Theater in der Josefstadt, Raimundtheater, Volkstheater and free theatre associations (Geschaeftsgruppe Kultur und Wissenschaft 2004: 119ff.). Most of these cultural facilities or activities have their focus in the inner districts of Vienna.

By contrast, comparatively few cultural programmes and facilities in the periphery of Vienna (districts 10 to 23) receive financial support from the municipality. A substantial part (2.3 mill. ) of the financial resources, devoted to cultural activities on the outskirts, is listed under the heading of every-day culture ("Alltagskultur"). This title comprises local art festivals ("Bezirksfestwochen") as well as other cultural activities by the districts and by the association Wiener Volksbildungswerk.

Further cultural initiatives or activities on the outskirts, which are supported by municipal funding, are local museums, Aktionsradius Augarten (in the 20 $20^{\text {th }}$ district), the cultural associations of the $11^{\text {th }}$ and $21^{\text {st }}$ district, Verein Kulturnetz that serves the northern parts of the city, the art festivals Soho in Ottakring and Art Position (both in the $16^{\text {th }}$ district), Planet music $\left(20^{\text {th }}\right)$, the local presentations by Volkstheater, associations or theatres such as IG

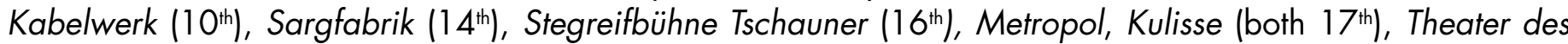
Augenblicks (18 $\left.18^{\text {th}}\right)$, Gloria Theater (21 $\left.1^{\text {st }}\right)$, Orpheum and Kaisermühlner Werkl (both $\left.22^{\text {nd }}\right)$. The city of Vienna also sponsors film, jazz and other festivals (Volxkino, Vienna Blues Spring etc.), which occasionally stretch out to the urban periphery (Geschaeftsgruppe Kultur und Wissenschaft 2004: 119ff.). Some of the local cultural initiatives attract additional funding by the state or the respective district.

Evidently there is a difference between political rhetoric and reality. Contrary to the presented facts, the Art and Culture Report 2004 praises funding of cultural facilities in the urban periphery by the municipality of Vienna. The respective labels for that are every-day culture and local cultural supply ("Nahversorgung Bezirkskultur"). Under the heading of every-day culture, the authors of the report write that urban qualities, which would diminish disparities between the centre and periphery, were strengthened. It is further said that cultural infrastructures in the urban periphery have improved, and that a colourful and multi-layered cultural life has evolved on the outskirts of the city (Geschaeftsgruppe Kultur und Wissenschaft 2004: $11 \mathrm{ff}$.).

In the light of the given focus of cultural funding by the municipality of Vienna, which concentrates on the inner districts, it represents no exaggeration to speak of the peripheral parts of Vienna as more or less blind spaces of urban cultural policy.

\section{Recent cultural developments on the fringes of Vienna}

Until the early 1990s, the peripheral districts of Vienna qualified more or less as a blind spot with regard to cultural infrastructure. The outer districts' supply of cultural facilities merely offered a few locations: the castle of Schönbrunn, two venues for big shows and concerts (Wiener Stadthalle, Kurhalle Oberlaa), a few remaining cinemas, some medium-sized venues for music, cabaret, theatre etc. (Szene Wien, Rockhaus, Kulisse, Metropol etc.), and the cultural programme presented by local museums and libraries as well as by institutions of adult education and youth centres. 
Table 1: New cultural initiatives on the fringes of Vienna (with a frequent programme by tendency)

\begin{tabular}{|c|c|c|}
\hline District & Cultural facilities/programmes & Type \\
\hline \multirow{2}{*}{ Favoriten (10th) } & Cineplexx Wienerberg im Twintower & multiplex cinema \\
\hline & Waldmuellerzentrum & various arts \\
\hline \multirow[t]{4}{*}{ Simmering $(11 \mathrm{th})$} & Bank-Austria-Halle & music \\
\hline & Hollywood Megaplex Gasometer & multiplex cinema \\
\hline & Movimento & music \\
\hline & Schloss Neugebaeude & $\begin{array}{l}\text { open air film show- } \\
\text { ings }\end{array}$ \\
\hline Meidling (12th) & Ketzerhof & various arts \\
\hline Hietzing (13th) & Zum lustigen Radfahrer & music \\
\hline \multirow[t]{2}{*}{ Penzing (14th) } & Cineplexx Wien Auhof im Auhofcenter & multiplex cinema \\
\hline & Sargfabrik & music \\
\hline \multirow[t]{3}{*}{ Rudolfsheim-Fuenfhaus (15th) } & Basis Wien/brick 5 & various arts \\
\hline & Blue Tomato & music \\
\hline & Lugner Kino City & multiplex cinema \\
\hline \multirow{9}{*}{ Ottakring (16th) } & Art Position & art exposition \\
\hline & Bach & music \\
\hline & Cafe Concerto & music \\
\hline & Club International & literature \\
\hline & MASC Foundation & fine art \\
\hline & Mezzanin/IP Two & music \\
\hline & Mio/Jazzmeile Ottakring & music \\
\hline & Soho in Ottakring & art festival \\
\hline & Vorstadt & music \\
\hline \multirow{2}{*}{ Hernals (17th) } & Artcafé & various arts \\
\hline & Café Jetzt & music \\
\hline Waehring (18th) & Theater des Augenblicks & theatre \\
\hline \multirow[t]{2}{*}{ Doebling (19th) } & Bamkraxler & music \\
\hline & Soul Veranda & music \\
\hline \multirow[t]{3}{*}{ Brigittenau (20th) } & Aktionsradius Augarten & various arts \\
\hline & \begin{tabular}{|l|} 
Shelter \\
\end{tabular} & music \\
\hline & UCI Kinowelt Millenium City & multiplex cinema \\
\hline \multirow[t]{4}{*}{ Floridsdorf (21st) } & \begin{tabular}{|l|} 
Davis \\
\end{tabular} & music \\
\hline & Gloria Theater & theatre \\
\hline & Hollywood Megaplex im SCN & multiplex cinema \\
\hline & Kulturkabinett & various arts \\
\hline \multirow[t]{6}{*}{ Donaustadt (22nd) } & Cineplexx Donauplex & multiplex cinema \\
\hline & Cineplexx Reichsbrücke & multiplex cinema \\
\hline & Gruam & theatre \\
\hline & Hopfhaus & various arts \\
\hline & Kaisermuehlner Werkl & theatre \\
\hline & Orpheum & theatre \\
\hline Liesing (23rd) & - & - \\
\hline
\end{tabular}

Source: Own compilation based on event calendars in "Falter", "Die Presse", "Wiener Zeitung", "Kurier", and various Internet sources.

In the late 1990s, a boom of new cultural facilities was launched on the outskirts of Vienna. Several innovative venues - basically for the performing arts, the fine arts, and film presentation - were established (see Table 1). Theater des Augenblicks (1 $8^{\text {th }}$ district), Gloria Theater (2 $\left.1^{\text {st }}\right)$, Gruam, Kaisermühlner Werkl, and Orpheum (all 
$\left.22^{\text {nd }}\right)$ present theatre and cabaret programmes. Bank Austria Halle, Movimento (both $11^{\text {th }}$ ), Zum lustigen Rad-

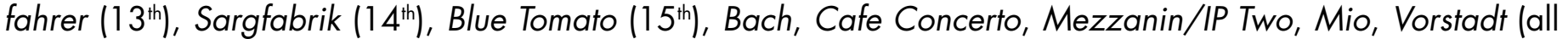
$\left.16^{\text {th }}\right)$, Café Jetzt $\left(18^{\text {th }}\right)$, Bamkraxler, Soulveranda (both 19th) Shelter $\left(20^{\text {th }}\right)$, and Davis $\left(21^{\text {st }}\right)$ are basically venues for music events. Waldmüllerzentrum $\left(10^{\text {th }}\right)$, Ketzerhof $\left(12^{\text {th }}\right)$, Basis Wien/brick5 $\left(15^{\text {th }}\right)$, Artcafé $\left(17^{\text {th }}\right)$, Aktionsradius Augarten $\left(20^{\text {th }}\right)$, Kulturkabinett $\left(21^{\text {st }}\right)$, and Hopfhaus $\left(22^{\text {nd }}\right)$ present various arts. In addition, there are the art fairs Soho in Ottakring and Art Position, the gallery MASC Foundation, Club International, a location for readings, as well as Jazzmeile Ottakring, a series of jazz concerts (all $16^{\text {th }}$ ). Eight multiplex cinemas in various districts and Schloss Neugebäude (1 $\left.1^{\text {th }}\right)$, a venue for open-air film showings, represent the film sector.

The cultural facilities do not only differ in their artistic presentations, but also in frequency of programmes, size and sources of finance. As Table 1 shows, some clusters of new cultural facilities are emerging in the $11^{\text {th }}$ district in the Southeast of Vienna, the $16^{\text {th }}$ district in the West, and in the $21^{\text {st }}$ and $22^{\text {nd }}$ districts in the North/Northeast.

\section{Research project New Culture on the Outskirts of Cities}

The research project New Culture on the Outskirts of Cities deals with the issues of culture and urban development. Basically, the project is inclined in offering theoretical contributions to the specific relationship of cultural facilities and urban peripheries and in developing recommendations for cultural policy and urban planning. Under theoretical premises, the project is based on geographical innovation and diffusion theory (Haegerstrand et al.), models of sustainable urban development (see Heineberg 2000), and on the findings of scientific work on culture and urban development (e.g. Bianchini 1993, Griffiths 1995, McCarthy 2002, Seo 2002 and Zukin 1998).

The results of previous research work on culture and urban development can be summarized as follows. At the beginning of the twenty-first century, the use of cultural projects as catalysts for urban development represents an established strategy. Within that strategy, cultural projects act as tools for the physical, spatial, economic, and social development of cities or distinct urban areas. Recent concepts of such issues are "cultural flagship projects" (Bianchini 1993: 5), "culture-orientated approaches to urban revitalization" (Griffiths 1995: 255), "entertainment-led regeneration" (McCarthy 2002: 105) or "cultural upgrading policy" (Seo 2002: 114).

Culture-orientated strategies for urban development can be implemented at the city level or at local level (quarters, districts, boroughs, neighbourhoods etc.). At city level, "cultural facilities and resources (...) have (...) become increasingly important complementary factors in the competition between cities possessing similar advantages" (Bianchini 1993: 18). At this level, large-scale cultural projects are primarily employed to create new, positive images for cities, which are of crucial importance for the competition of cities. Glasgow (European Capital of Culture in 1990) and Bilbao, for instance, successfully shifted the presentation of their external images as an industrial centre to that of a cultural city. Liverpool, designated Capital of Culture for 2008, will try to follow these examples.

Cultural initiatives at the local level - which are at the focus of the mentioned project - primarily encourage an upgrading of disadvantaged areas or districts. In Europe these are frequently peripheral or semi-peripheral areas of cities. Among the possible effects of an improvement of the local cultural infrastructure are a certain cultural self-reliance of fringe areas, the democratisation of culture, an improvement of living conditions, the integration of different parts of the population, the creation of a distinct identity of the outskirts and a stronger identification of the population with their habitat. 
In practical terms it is often difficult to classify the specific cultural projects and to relate them either to the city or the local level. The boundaries between these two levels often are blurred. Possible differentiations exist according to the scope and the primary purpose of the venues. Large-scale cultural projects - regardless of the area of the city in which they are situated - frequently are designed as flagship projects for the enhancement of a city's image or serve the needs of the population of the entire city. Smaller venues mostly serve the needs of the local population and foster an upgrading of distinct city areas.

Within the framework of the project, the following basic research questions will be answered.

First: What are the basic characteristics of the new cultural initiatives on the outskirts? This relates to the major actors of the respective project, legal structures, ways of financing, aims, different types of art presentation, networks, and the specific location of the cultural facilities as well as to catchment areas of visitors and participants.

Second: What are the driving forces for this cultural boom on the outskirts of cities? Do push factors, such as processes of decentralisation, or pull factors determine the establishment of new cultural venues? Among the latter might be residents' initiatives, a certain lack of cultural infrastructures in the peripheral areas, comparatively lower prices for housing, rents or vacancies of shops and flats.

Third: In which ways do (new) cultural facilities contribute to a positive development of peripheral or semi-peripheral areas in cities, and which recommendations can be offered for cultural policy and urban planning?

The project's research methodology comprises quantitative and qualitative elements. Among the methods applied are a documentation of new cultural initiatives in the (semi-) peripheries of Vienna, Paris and Rome, participatory observation, a questionnaire-based survey of visitors of cultural facilities, in-depth interviews with main project actors as well as interviews with experts in the field of culture, urban planners and politicians.

\section{Main findings: Comparison of cultural trends in Vienna, Paris and Rome, cultural facilities' effects on urban development and policy recommendations}

In the course of the current research project, cultural developments in peripheral or semi-peripheral areas in Vienna, Paris and Rome are studied. For the case study on Vienna, the districts Ottakring (16 th) in the West and Floridsdorf (2 $1^{\mathrm{st}}$ ) in the North were selected. The area studied in Paris is Ménilmontand, the $20^{\text {th }}$ arrondissement in the East of the French capital. For Rome the semi-peripheral Testaccio/Ostiense quarter (south of the Colosseum) was chosen.

In the $16^{\text {th }}$ and $21^{\text {st }}$ districts of Vienna a lively scene of recently established cultural venues like theatres, music clubs, galleries, art festivals, locations for various arts, and multiplex cinemas has emerged (see Chapter 3 ). The cultural scene of the $20^{\text {th }}$ district in Paris developed in some ways as a spatial extension of the respective scenes in the Opéra Bastille and Oberkampf quarters. Ménilmontand houses two theatres with a state funding (Théâtre National de la Colline, Théâtre de l'Est Parisien), a broad range of private theatres (Vingtième Théâtre, Comédie de la Passarelle, Théâtre de Ménilmontand, Théâtre les Enfants Terribles, Théâtre des Quarts d heure etc.), some music cafes (Lou Pascalou, Oh 20) and facilities for various arts (La Maroquinerie, Confluences - Maison des Arts Urbains etc.). Further cultural events are organised by artists associations, by the district municipality or by the district's neighbourhood councils.

Teatro Vittoria, which was established in the early 1980s, qualifies as a forerunner of new cultural facilities in the Testaccio/Ostiense quarter in Rome. Testaccio hill, a giant heap of ancient amphorae, gave the name to the area south of the Colosseum. The current cultural infrastructure of the Testaccio/Ostiense quarter is made up by theatres such as Nuovo Teatro Spazio Zero, Teatro dei Cocci and the above mentioned Teatro Vittoria, Greenwich cinema, music clubs like Radio Londra Caffè, discotheques (Jungle Club, Zoobar) and trendy restaurants at Testaccio hill. MACRO al Mattatoio, the second site of the city of Rome's Museum of Contempory Art, is located 
in a former slaughter house. Also situated at the ex-slaughter house is Villagio Globale - Centro Sociale, a venue for music, theatre and political activities.

Within the context of a comparison between cultural developments in Vienna, Paris and Rome, the following can be stated. What Vienna, Paris and Rome have in common are the still existing huge differences between centre and periphery with regard to density of the cultural infrastructure. The three cities, furthermore, rely on a dual system (state, municipality) of cultural funding. Another similarity is the vibrant scene of recently established cultural facilities in the three case study areas.

A crucial difference between Vienna, Paris and Rome refers to the decentralisation of major cultural institutions and the political and financial support for peripheral cultural facilities in general. In the case of Paris and Rome, high priority is given to the cultural development of the cities' peripheries. In Paris the decentralisation of major cultural institutions already started in the late 1980s with Bastille opera (12 $2^{\text {th }}$ district) and the Science Museum

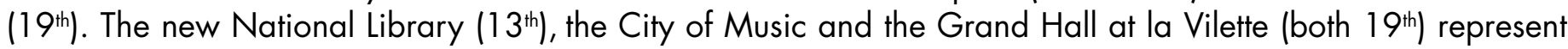
more recent examples for that strategy. In Rome the Music Area (Parco della Musica) and MAXXI, the National Museum of the Arts of the $21^{\text {st }}$ Century, (both in the northern part) as well as the cited second site of MACRO were recently built in the city's remote areas. For Vienna, only the new central library at the Urban Loritz square and the recent extension of Wiener Stadthalle may be cited as relevant examples.

It is not only the decentralisation of major cultural institutions that makes the difference between Paris and Rome on the one hand and Vienna on the other hand, but here also the support for peripheral areas' smaller cultural facilities adds in. Walter Veltroni, the current major of Rome, explained the rationale for the latter by highlighting the function of theatres, sports facilities and libraries for creating neighbourhoods worthwhile-living-in as well as for preventing crime (Metropolis, Arte, March 27 2004).

On the basis of previous scientific work and the preliminary outcomes of the project New Culture on the Outskirts of Cities, a typology of effects of cultural facilities on the development of urban (semi-) peripheries can be proposed for discussion. The depicted research work shows that cultural initiatives are in a position of stimulating the cultural, economic and social development of peripheral parts of cities. In terms of the facilities' impact on those areas, a distinction should be drawn between effects in the field of culture (immediate effects) and consequences for urban development in general (indirect outcomes).

Effects in the cultural field are

- the advancement of the peripheral areas' cultural autonomy;

- an increased democratisation of culture; and

- a decentralisation of leisure activities.

Effects on urban development in general can be

- the encouragement of urban regeneration;

- an improvement of living conditions (problem of gentrification);

- the creation of jobs and stimulation of creative industries;

- the promotion of retail trade;

- a reduction of leisure-related traffic;

- the integration of different segments of the population;

- an increased political participation of citizens;

- the creation of a distinct identity of the outskirts (particularly for areas with recent housing stock); and

- a stronger identification of the population with their habitat. 
As the typology of effects demonstrates, there is a lot to gain from the political and financial support of cultural facilities in the urban peripheries. For the purpose of fully leveraging these listed effects, municipalities have to obey the following.

First: Cultural initiatives should be truly understood as tools for the physical, spatial, economic, and social development of peripheral city areas (see Chapter 4).

Second: Another prerequisite for such a culture-oriented strategy of urban development is the willingness of the city administration, to improve living conditions in disadvantaged areas.

Third: Under the given circumstances, the support for cultural facilities on the outskirts might necessitate a partial shift of financial resources to peripheral areas.

Finally, some recommendations shall be designed for a cultural policy in support of the peripheral areas' cultural facilities. Such a policy should comprise

- the creation of cultural lead projects in peripheral districts;

- the provision of appropriate funding for cultural facilities;

- a supply of adequate locations for theatre productions, exhibitions, performances, film showings, concerts etc.;

- the creation of a pool of experts (art, management, etc.) for the advancement of cultural facilities in the urban peripheries;

- a support for the networking of cultural initiatives (within and beyond city boundaries);

- an encouragement of public-relation activities for cultural projects (advertisement, websites, etc.); and, last but not least,

- the promotion and (better) funding of research about cultural facilities in the urban peripheries.

Despite the dynamics of an emerging scene of new cultural facilities on the outskirts of Vienna, the bulk of public resources still focuses on cultural facilities and events in the city's inner districts. Thus, the city's peripheral areas represent more or less blind spaces for the municipality's cultural policy. We could show that cultural facilities are in a position of delivering a valuable contribution for the creation of vibrant cities. Therefore, there is a pay-off tied to efforts for encouraging and supporting cultural initiatives in urban fringe areas. It is up to the municipality of Vienna to capture this opportunity.

\section{References}

Bianchini, F. 1993. "Remaking European Cities: The Role of Cultural Policies," in Cultural Policy and Urban Regeneration: The West European Experience, F. Bianchini and M. Parkinson, eds., Manchester, New York: Manchester University Press, p. 1-20.

Bianchini, F. and L. Ghilardi 1997. Culture and Neighbourhoods: A Comparative Report. Santacatterina, Strasbourg: Council of Europe.

Centre Tricontinental, ed. 2000. Cultures et mondialisation. Résistances et alternatives. Point de vue sud - Centre Tricontinental. Paris: L'Harmattan.

Eckardt, F. and P. Kreisl, eds. 2004. City Images and Urban Regeneration. The European Cities in Transition Series, Vol. 3. Frankfurt am Main: Peter Lang.

Florida, R. 2002. The Rise of the Creative Class. And How it's Transforming Work, Leisure, Community and Everyday Life. New York: Basic Books.

Geschaeftsgruppe Kultur und Wissenschaft, ed. 2004. Kunst- und Kulturbericht der Stadt Wien 2004. Geschaeftsgruppe Kultur und Wissenschaft des Magistrats der Stadt Wien. Wien. http://www.wien.gv.at/kultur/abteilung/pdf/kunstbericht2004a.pdf/http:// www.wien.gv.at/kultur/abteilung/pdf/kunstbericht2004b.pdt http://www.wien.gv.at/kultur/abteilung/pdf/foerderungen2004.pdf (30.4.2006).

Grand Lyon Prospective, ed. 1999. Les politiques culturelles. Face aux dynamiques sociales et métropolitaines. Les cahiers Millénaire trois - no. 19. Lyon. 
Griffiths, R. 1995. "Cultural Strategies and New Modes of Urban Intervention.", Cities, Vol. 12, no. 4, 1995. p. $253-265$.

Heineberg, H. 2000. Grundriss Allgemeine Geographie: Stadtgeographie. Paderborn u.a.: Schoeningh/UTB.

Holden, J., 2004. Capturing Cultural Value. How Culture Has Become a Tool of Government Policy. London: Demos. http://www.demos. co.uk/catalogue/culturalvalued (30.4.2006).

Kirchberg, V. and A. Goeschel, eds. 1998. Kultur in der Stadt. Stadtsoziologische Analysen zur Kultur. Opladen: Leske und Budrich.

Landry, Ch. and F. Bianchini 1995. The Creative City. London: Demos/Comedia. http://www.demos.co.uk/catalogue/thecreativecity/ (30.4.2006).

Lindner, R. 2000. "Stadtkultur," in Grossstadt. Soziologische Stichworte, H. Haeussermann, ed., Opladen: Leske und Budrich, p. 258264.

McCarthy, J. 2002. "Entertainment-led Regeneration: The Case of Detroit." Cities, Vol. 19, no 2, 2002, p. $105-111$.

Metropolis, Arte, March 272004.

Mitchell, D. 2000. Cultural Geography. A Critical Introduction. Malden, Oxford, Carlton South, Berlin: Blackwell.

Ratzenboeck, V. et al., eds. 1995. Kulturpolitik und Restrukturierung der Stadt. Wien, Salzburg.

Ritter, W. 1998. Allgemeine Wirtschaftsgeographie. Eine systemtheoretisch orientierte Einfuehrung. Muenchen-Wien: Oldenbourg Verlag.

Rohn, W. 2001. "New Cultural Institutions on the Outskirts of Vienna," in Call for Papers: Abstracts. Urban Renewal, International Federation for Housing and Planning, International Congress, Barcelona, September 9-13 2001, p. 42-43.

Rohn, W. 2003. "Wien. Die neue Kultur an der Peripherie der Stadt." dérive, Vol. 4, no 2, 2003, p. 30-31.

Rohn, W. 2004a. "Culture and Urban Development. New Cultural Infrastructures on the Outskirts of Vienna and Paris," in European Cities. Insights on Outskirts. Structures, Cost C10 Publications and Papers. WG 2 - Structures, A. Borsdorf and P. Zembri, eds., Paris, p. 149-167. http://www.qub.ac.uk/ep/research/costc10/findoc/struct.pdt (30.4.2006).

Rohn, W. 2004b. "Aktuelle Tendenzen der Dezentralisierung von Kultureinrichtungen in Wien und Paris," in Konvergenz und Divergenz der Kulturen in den Randzonen der Staedte, Beitraege der Sektion 3.7 der internationalen Konferenz Das Verbindende der Kulturen, Veranstaltung des INST von 7. bis 9. November 2003, Wien, Schriftenreihe Wohnwesen Umland Wien, Band 2, A. Borsdorf and V. Mayer, eds., p. 37-46. http://www.inst.at/trans/15Nr/03_7/rohn15.htm (30.4.2006).

Rohn, W. 2005. "'Making Use of Culture' for Local Urban Development: Typology of the Effects of Small Cultural Facilities on the Development of Urban Peripheries," in Making Use of Culture/Abstracts. Inaugural Conference of the Cultural Theory Institute, University of Manchester, January 21-23 2005, p. 59.

Staudacher, C. 2000. Wirtschaftsgeographie-VL. Eine Einfuehrung. bfi Wien Euroteam-Fachhochschul-Studiengangsbetriebs-Gesellschaft m.b.H. Wien.

Seo, J.-K. 2002. "Re-urbanisation in Regenerated Areas of Manchester and Glasgow." Cities, Vol. 19, no 2, 2002, p. $113-121$.

Smiers, J. 2003. Arts Under Pressure. Promoting Cultural Diversity in the Age of Globalisation. London: Zed Books.

Stadtentwicklung Wien, ed. 2005. STEP 05 - Stadtentwicklungsplan Wien 2005. Stadtentwicklung Wien, Magistratsabteilung 18, Stadtentwicklung und Stadtplanung. Wien.

Wehrli-Schindler, B. 2002. "Kulturelle Einrichtungen als Impulsgeber fuer Stadtentwicklung? Beobachtungen am Beispiel Zuerich West." DISP, Vol. 38, no 3, 2002, p. 4-10.

Zukin, S. 1998. "Staedte und die Oekonomie der Symbole," in Kultur in der Stadt. Stadtsoziologische Analysen zur Kultur, V. Kirchberg and A. Goeschel, eds., Opladen: Leske und Budrich, p. 27-40. 